\title{
NGHIÊN CỨU ĐẶC ĐIỂM LÂM SÀNG, CẬN LÂM SÀNG VÀ KẾT QUẢ ĐIỀU TR! VIÊM MỦ MÀNG NGOÀITIM Ở TRẺ EM TẠI BỆNH VIỆN NHI TRUNG ƯơNG
}

\author{
Ngô Thị Hương ${ }^{1}$, Đặng Thị Hải Vân² Lê Thị Phượng ${ }^{3}$ \\ 1. Bệnh viện Hũu Nghị Lạc Việt - Vĩnh Phúc, 2. Đại học Y Hà Nội, 3. Bệnh viện Nhi Trung ương
}

\section{TÓM TẮT}

Mục tiêu: Xác định đặc điểm lâm sàng, cận lâm sàng và kết quả điều trị viêm mủ màng ngoài tim ở trẻ em tại Bệnh Viện Nhi Trung ương. Đối tượng và phương pháp: Nghiên cứu trên 42 bệnh nhân viêm mủ màng ngoài tim tại Bệnh viện Nhi Trung ương từ 09/2015-08/2020. Kết quả: Tuổi trung bình nhập viện là $5,4 \pm 4,5$ tuổi tỷ lệ nam/nữ là 1,6/1. Triệu chứng thường gặp là sốt $97,6 \%$; khó thở 76,2\%; tiếng tim mờ 66,7\%; mạch nhanh 71,4\%; gan to 59,5\%; đau ngực 52,4\%. Phản ứng viêm xuất hiện ở hâu hết các bệnh nhân với tăng bạch câu máu ngoại vi (81\%); tăng CRP (100\%). Cấy máu dương tính chiếm tỷ lệ thấp (19\%); cấy dịch màng tim dương tính chiếm $35,7 \%$ trong đó $86,7 \%$ là S. aureus và $13,3 \%$ là S. pyogen. Siêu âm tim $100 \%$ có tràn dịch màng ngoài tim mức độ trung bình hoặc nặng, 61,9\% có xẹp nhĩ phải, 81,0\% dịch có fibrin. Điều trị nội khoa gồm kháng sinh $100 \%$ trong đó thường dùng nhất là vancomycin (83,3\%) và cefalosporin thế hệ 3(81\%). Có 35,7 \% bệnh nhân chỉ cân điều trị nội khoa với chọc dịch hoặc dẫn lưu dịch màng ngoài tim. Điều trị ngoại khoa gồm phẫu thuật cắt màng ngoài tim (52,4\%); mổ dẫn lưu dịch màng ngoài tim (7,1\%) và mở cửa sổ màng ngoài tim (4,8\%). Kết quả điêu trị không có bệnh nhân nào tử vong, 2 trường hợp $(4,8 \%)$ có biến chứng viêm màng ngoài tim co thắt. Kết luận: Viêm mủ màng ngoài tim ở trẻ em là bệnh ít gặp nhưng có thể gây tử vong nếu không được chẩn đoán và điều trị kịp thời. Triệu chứng lâm sàng đa dạng, không đặc hiệu, dễ nhầm lẫn với bệnh khác. Tác nhân thường gặp nhất là S. aureus. Điều trị phối hợp nội ngoại khoa cho kết quả tốt.

Từ khóa: Viêm mủ màng ngoài tim, trẻ em.

\section{ABSTRACT \\ STUDY ON CLINICAL, SUBCLINICAL CHARACTERISTICS AND TREATMENT RESULTS OF PURULENT PERICARDITIS IN CHILDREN AT THE VIET NAM NATIONAL CHILDREN'S HOSPITAL}

Objectives: To determine clinical, subclinical, treatment and treatment outcomes for purulent pericarditis in children at the National Children's Hospital. Patients and methods: Research on 42 patients with purulent pericarditis at Central Children's Hospital, between09/2015 - 08/2020. Results: Average age is $5.4 \pm 4.5$; The ratio of male/female is $1.6 / 1$. Common symptoms are fever $97.6 \%$; breathlessness $76.2 \%$; diminished heart sound $66.7 \%$; $71.4 \%$ tachycardia; $59.5 \%$ hepatomegaly; chest pain $52.4 \%$. Inflammatory reactions appear in most patients with increasing

Nhận bài: 12-12-2020; Chấp nhận: 10-2-2021

Người chịu trách nhiệm chính: Ngô Thị Hương

Địa chỉ: Bệnh viện Hữu Nghị Lạc Việt - Vĩnh Phúc 
leukocytosis (81\%); increasing CRP (100\%). The positive blood culture was $19 \%$ and the positive pericardial fluid culture was $35.7 \%$ of which $86.7 \%$ was S. aureus and $13.3 \%$ was S. pyogen. $100 \%$ echocardiography had moderate or severe pericardial effusion, of which $61.9 \%$ was severe effusion, $61.9 \%$ had collapsed right atrium, $81.0 \%$ fluid had fibrin. The treatment includes $100 \%$ antibiotics, of which the most commonly used are vancomycin (83.3\%) and 3rd generation cefalosporin (81\%); pericardial drainage and drains the pericardial fluid(35.7\%). Surgical treatment includes pericardiectomy (52.4\%); drains the pericardial fluid surgery $(7.1 \%)$ and opens the pericardial window (4.8\%). No patient died as a result of treatment, only 2 cases (4.8\%) had Pick syndrome. Conclusion: Pericarditis is uncommon disease however it can results in high mortality unless it is early diagnosis and management. Patients usually have various non-specific symptoms and misdiagnosed with other cardiac diseases. Most cases are caused by bacteria, especially S.aureus. Echocardiography still plays an important role in early diagnosis of pericarditis so far. Antibiotic therapy and surgery intervention help improve the outcome.

Key words: Purulent pericarditis, children.

\section{1. ĐẶT VẤN ĐỀ}

Bệnh màng ngoài tim là một trong những bệnh lý thường gặp của bệnh tim mắc phải, trong đó viêm màng ngoài tim là bệnh thường gặp nhất [1]. Ở một đất nước đang phát triển như Việt Nam thì viêm mủ màng ngoài tim (VMMNT) vẫn là một nguyên nhân chính gây viêm màng ngoài tim [2]. Viêm mủ màng ngoài tim là tình trạng nhiễm trùng khu trú khoang màng ngoài tim đặc trưng bởi sự xuất hiện mủ thô hoặc vi thể trong khoang màng ngoài tim[1]. Bệnh có thể gây tử vong nếu không được chẩn đoán sớm và điều trị kịp thời. Với bệnh cảnh lâm sàng đa dạng dễ nhầm với nhiều bệnh lý hô hấp và lồng ngực khác nên có thể bị bỏ sót và chẩn đoán muộn gây ra những hậu quả nặng nề về sức khỏe của trẻ cũng như tăng chi phí điều trị làm tăng gánh nặng cho gia đình và xã hội. Vậy vi khuẩn gây viêm mủ màng ngoài tim và kết quả điều trị viêm mủ màng ngoài tim ở trẻ em đã thay đổi như thế nào trong thời gian gần đây? Để trả lời cho câu hỏi này, chúng tôi tiến hành nghiên cứu với 2 mục tiêu:

1. Mô tả biểu hiện lâm sàng, cận lâm sàng viêm mủ màng ngoài tim ở trẻ em tại Bệnh viện Nhi Trung ương.

2. Nhận xét kết quả điều trị viêm mủ màng ngoài tim tại Bệnh viện Nhi Trung ương.

\section{2. ĐốITƯợNG VÀ PHƯơNG PHÁP NGHIÊN CỨU}

\section{1. Đối tượng nghiên cứu}

- Tuổi: 0-15 tuổi

- Được xác định có tràn dịch màng ngoài tim dựa trên kết quả siêu âm của bác sĩ chuyên khoa tim mạch trẻ em.

- Được lấy dịch khoang MNT (chọc hút/dẫn lưu/phẫu thuật), dịch MNT là:

+ Dịch đục hoặc dịch mủ

+ Có BC đa nhân thoái hóa

- Tiêu chuẩn loại trừ:

+ Bệnh án hồi cứu không đủ thông tin

+ Bệnh nhân được chẩn đoán có tràn dịch màng ngoài tim nhưng chọc hút dịch MNT không phải là dịch mủ hoặc dịch đục và xét nghiệm không có tế bào bạch cầu đa nhân thoái hóa

\subsection{Phương pháp nghiên cứu}

Nghiên cứu mô tả với cỡ mẫu thuận tiện trong thời gian từ tháng 9/2015 tới tháng 8/2020, trong đó nhóm hồi cứu gồm những bệnh nhân nhập viện từ tháng 9/2015 đến tháng6/2018 và nhóm tiến cứu gồm những bệnh nhân nhập viện từ tháng 7/2018 đến tháng 8/2020.

- Các biến số về đặc điểm chung (tuổi, giới); lâm sàng (triệu chứng cơ năng, thực thể); chỉ số 
tim ngực, giảm điện thế, thay đổi đoạn ST trên điện tâm đồ; siêu âm tim (mức độ tràn dịch, tích chất dịch trên siêu âm, tình trạng dày màng tim); xét nghiệm (chỉ số bạch cầu máu ngoại vi, CRP procalcitonin; kết quả cấy máu); dịch KMNT (màu sắc, số lượng..); các biến số liên quan đến điều trị (chẩn đoán và điều trị ở tuyến trước, các thuốc sử dụng, phương pháp can thiệp/phẫu thuật tháo dịch KMNT). Chẩn đoán mức độ tràn dịch theo Hội Tim mạch châu Âu: ${ }^{1}$

+ TDMT mức độ nhẹ: Khoảng trống siêu âm trong thì tâm trương $<10 \mathrm{~mm}$.

+ TDMT mức độ trung bình: Khoảng trống siêu âm trong thì tâm trương từ $10-20 \mathrm{~mm}$.

+ TDMT mức độ nặng: Khoảng trông siêu âm trong thì tâm trương $>20 \mathrm{~mm}$.

2.3. Phương pháp phân tích và xử lý số liệu: Số liệu được xử lý theo thuật toán thống kê bằng phần mềm SPSS 20.0.

\section{KẾT QUẢ}

Trong thời gian từ tháng 9/2015 đến tháng 8/2020 có 42 bệnh nhân tại Bệnh viện Nhi Trung ương đáp ứng tiêu chuẩn được đưa vào nghiên cứu.

\section{1. Đặc điểm chung}

Trong 42 bệnh nhân có 26 bệnh nhân nam và 16 bệnh nhân nữ, tỷ lệ nam/nữ là 1,6/1.

Tuổi mắc bệnh trung bình là $5,4 \pm 4,3$ tuổi; nhỏ nhất gặp ở trẻ 1 tháng tuổi, lớn nhất là 15 tuổi.

\section{2. Đặc điểm lâm sàng và cận lâm sàng}

\subsection{1. Đặc điểm lâm sàng}

Dựa vào kết quả siêu âm tim của 42 bệnh nhân trong nghiên cứu, chúng tôi chia bệnh nhân thành 2 nhóm: nhóm tràn dịch màng ngoài tim mức độ nặng gồm 26 bệnh nhân (chiếm 61,9\%) và nhóm tràn dịch mức độ trung bình gồm 16 bệnh nhân (chiếm 38,1\%). Không có bệnh nhân nào tràn dịch mức độ nhẹ.

Bảng 1. Các triệu chứng lâm sàng

\begin{tabular}{|c|c|c|c|c|c|c|c|}
\hline \multirow[t]{2}{*}{ Triệu chứng } & \multicolumn{2}{|c|}{$\begin{array}{l}\text { Chung } \\
n=42\end{array}$} & \multicolumn{2}{|c|}{$\begin{array}{l}\text { Tràn dịch } \\
\text { trung bình } \\
n=16\end{array}$} & \multicolumn{2}{|c|}{$\begin{array}{l}\text { Tràn dịchnặng } \\
n=26\end{array}$} & \multirow[t]{2}{*}{$\mathbf{p}$} \\
\hline & $\mathbf{n}$ & $\%$ & $\mathbf{n}$ & $\%$ & $\mathbf{n}$ & $\%$ & \\
\hline Sốt & 41 & 97,6 & 16 & 100,0 & 25 & 96,2 & 0,43 \\
\hline Khó thở & 32 & 76,2 & 9 & 56,2 & 23 & 88,5 & 0,23 \\
\hline Phù & 4 & 9,5 & 1 & 6,2 & 3 & 11,5 & 0,57 \\
\hline Gan to & 25 & 59,5 & 8 & 50,0 & 17 & 65,4 & 0,32 \\
\hline TMC nổi & 14 & 33,3 & 2 & 12,5 & 12 & 46,1 & 0,07 \\
\hline Mạch nhanh & 30 & 71,4 & 8 & 50,0 & 22 & 84,6 & 0,016 \\
\hline Mạch nghịch & 8 & 19,0 & 0 & 0,0 & 8 & 30,8 & 0,025 \\
\hline Tiếng tim mờ & 28 & 66,7 & 14 & 87,5 & 14 & 53,8 & 0,072 \\
\hline Tiếng cọ MNT & 4 & 9,5 & 0 & 0,0 & 4 & 15,4 & 0,063 \\
\hline Huyết áp hạ & 23 & 54,8 & 2 & 12,5 & 21 & 80,8 & $<0,01$ \\
\hline
\end{tabular}

Nhận xét:

- Các triệu chứng mạch nhanh, mạch nghich và huyết áp hạ là có sự khác biệt có ý nghĩa thống kê giữa 2 nhóm tràn dịch mức độ nặng và trung bình $(p<0,05)$.

- Có 27/42 bệnh nhân có triệu chứng kèm theo tại cơ quan khác với 14/42 (33,3\%) bệnh nhân có tràn dịch màng phổi và viêm phế quản phổi đồng thời; $52,4 \%$ bệnh nhân chỉ có tràn dịch màng phổi kèm theo; $45,2 \%$ chỉ có viêm phế quản phổi; $16,7 \%$ có viêm da và mô mềm; $2,4 \%$ có viêm cơ kèm theo, không có bệnh nhân nào có cốt tủy viêm và viêm màng não mủ. Một bệnh nhân có thể tổn thương nhiều cơ quan kèm theo. 


\subsection{2. Đặc điểm cân lâm sàng}

Bảng 2. Đặc điểm Xquang, điện tâm đồ và siêu âm tim

\begin{tabular}{|c|c|c|c|c|c|c|c|c|}
\hline \multirow{2}{*}{\multicolumn{2}{|c|}{ Thông số }} & \multicolumn{2}{|c|}{$\begin{array}{l}\text { Chung } \\
n=42\end{array}$} & \multicolumn{2}{|c|}{$\begin{array}{l}\text { Tràn dịch } \\
\text { trung bình } \\
n=16\end{array}$} & \multicolumn{2}{|c|}{$\begin{array}{l}\text { Tràn dịch } \\
\text { nặng } \\
\mathbf{n}=\mathbf{2 6}\end{array}$} & \multirow{3}{*}{$\mathbf{p}$} \\
\hline & & $\mathbf{n}$ & $\%$ & $\mathbf{n}$ & $\%$ & $\mathbf{n}$ & $\%$ & \\
\hline \multicolumn{2}{|r|}{ Xquang tim phổi thẳng } & & & & & & & \\
\hline \multirow{5}{*}{ Tỷ lệ tim ngực } & $<55 \%$ & 0 & 0,0 & 3 & 18,8 & 0 & 0,0 & \multirow{4}{*}{0,046} \\
\hline & $55-60 \%$ & 2 & 15,4 & 6 & 37,5 & 9 & 34,6 & \\
\hline & $60-70 \%$ & 8 & 61,4 & 7 & 43,8 & 12 & 46,2 & \\
\hline & $>70 \%$ & 3 & 23,1 & 0 & 0,0 & 5 & 19,2 & \\
\hline & Trung bình \pm SD & \multicolumn{2}{|c|}{$62,2 \pm 6,2$} & \multicolumn{2}{|c|}{$58,4 \pm 5,2$} & \multicolumn{2}{|c|}{$63,7 \pm 5,9$} & 0,42 \\
\hline \multicolumn{2}{|l|}{ Hình tim 2 bờ } & 8 & 19,0 & 3 & 18,8 & 5 & 19,2 & 0,97 \\
\hline \multicolumn{9}{|c|}{ Điện tâm đồ } \\
\hline \multirow{3}{*}{$\begin{array}{l}\text { Dấu hiệu giảm } \\
\text { điện thế [4] }\end{array}$} & Không có giảm điện thế & 22 & 52,4 & & & & & \\
\hline & Điện thế ngoại biên $\leq 5 \mathrm{~mm}$ & 17 & 40,5 & 4 & 25,0 & 13 & 50,0 & 0,11 \\
\hline & Điện thế chuyển đạo trước tim $\leq 10 \mathrm{~mm}$ & 5 & 11,9 & 2 & 12,5 & 3 & 11,5 & 0,93 \\
\hline \multirow{3}{*}{$\begin{array}{l}\text { Dấu hiệu thay đổi } \\
\text { đoạn ST và sóng } \\
\text { T trên các chuyển } \\
\text { đạo ngoại biên và } \\
\text { trước tim [5] }\end{array}$} & Không thay đổi & 23 & 54,8 & & & & & \\
\hline & $\begin{array}{l}\text { ST chênh lên, sóng } \mathrm{T} \text { dương lan rộng ở } \\
\text { nhiều chuyển đạo ngoại biên và trước tim } \\
\text { (trừ aVR) }\end{array}$ & 8 & 19,0 & 3 & 18,8 & 5 & 19,2 & \multirow[t]{2}{*}{0,84} \\
\hline & ST chênh xuống hoặc đẳng điện, sóng $\mathrm{T}$ âm & 11 & 26,2 & 5 & 31,3 & 6 & 23,1 & \\
\hline \multicolumn{9}{|c|}{ Siêu âm tim } \\
\hline \multicolumn{2}{|l|}{ Có xẹp nhĩ phải } & 26 & 61,9 & 4 & 25,0 & 22 & 84,6 & $<0,01$ \\
\hline \multicolumn{2}{|c|}{ Có xẹp nhĩ và thất phải } & 10 & 23,8 & 0 & 0,0 & 10 & 34,5 & 0,04 \\
\hline \multirow{2}{*}{ Tính chất dịch } & Không có fibrin & 8 & 19,0 & 1 & 6,3 & 7 & 26,9 & \multirow{2}{*}{0,98} \\
\hline & Có fibrin & 34 & 81,0 & 15 & 93,8 & 19 & 73,1 & \\
\hline \multicolumn{2}{|l|}{ Có dày màng tim } & 15 & 35,7 & 7 & 43,8 & 8 & 30,8 & 0,4 \\
\hline
\end{tabular}

\section{Nhận xét:}

$97,6 \%$ bệnh nhân có tỷ lệ tim ngực tăng (>55\% với trẻ dưới 2 tuổi và $>50 \%$ với trẻ trên 2 tuổi). Chỉ có 1 bệnh nhân có chỉ số tim ngực không tăng, bệnh nhân này đã được chọc dịch MNT ở tuyến dưới và được siêu âm tim tại Bệnh viện Nhi Trung ương 1 ngày sau khi chụp Xquang tim phổi với mức độ TDMNT trung bình - nhẹ; tỷ lệ tim ngực > $60 \%$ ở nhóm tràn dịch mức độ nặng $(65,4 \%)$ cao hơn có ý nghĩa so với nhóm tràn dịch mức độ trung bình $(43,8 \%)$.

- Thay đổi trên điện tâm đồ không có sự khác biệt giữa 2 nhóm tràn dịch mức độ trung bình và mức độ nặng ( $p>0,05)$.

- Dấu hiệu xẹp nhĩ phải, dấu hiệu xẹp nhĩ và xẹp thất phải trên siêu âm có sự khác biệt giữa 2 nhóm $(p<0,05)$. 
TẠP CHÍ NHI KHOA 2021, 14, 1

Bảng 3. Kết quả xét nghiệm máu và dịch màng tim

\begin{tabular}{|c|c|c|c|}
\hline \multicolumn{4}{|c|}{ Xét nghiệm máu } \\
\hline \multicolumn{2}{|c|}{ Thông số } & \multicolumn{2}{|c|}{ Kết quả } \\
\hline Bạch cầu (G/L) (n =42) & Trung bình (Min - Max) & \multicolumn{2}{|c|}{$18,3 \pm 10,1(2,2-64,1)$} \\
\hline $\operatorname{CRP}(m g / l)(n=42)$ & Trung bình (Min - Max) & \multicolumn{2}{|c|}{$108,4 \pm 75,4(22,0-281,6)$} \\
\hline Procalcitonin $(\mathrm{ng} / \mathrm{ml})(\mathrm{n}=38)$ & Trung vị (Min - Max) & \multicolumn{2}{|c|}{$2,3(0,09-31,2)$} \\
\hline Cấy máu (n = 42) & $\begin{array}{l}\text { Dương tính n (\%) } \\
\text { S. aureus } \\
\text { S. pyogenes }\end{array}$ & \multicolumn{2}{|c|}{$\begin{array}{c}8(19,0) \\
7(16,6)) \\
1(2,4)\end{array}$} \\
\hline \multicolumn{4}{|c|}{ Xét nghiệm dịch màng ngoài tim } \\
\hline \multicolumn{2}{|c|}{ Thông số } & Số BN & Tỷ lệ \% \\
\hline Bệnh nhân được lấy dịch KMNT $(n=42)$ & $\begin{array}{l}\text { Chọc hút dịch } \\
\text { Lấy khi phẫu thuật }\end{array}$ & $\begin{array}{l}19 \\
23\end{array}$ & $\begin{array}{l}45,2 \\
54,8\end{array}$ \\
\hline Màu sắc (n=42) & $\begin{array}{l}\text { Đục } \\
\text { Mủ }\end{array}$ & $\begin{array}{l}28 \\
14\end{array}$ & $\begin{array}{l}66,7 \\
33,3\end{array}$ \\
\hline Số lượng BC trong $1 \mu \mathrm{l}$ dịch $(\mathrm{n}=42)$ & $\begin{array}{l}\leq 500 \\
500-1000 \\
>1000\end{array}$ & $\begin{array}{l}13 \\
11 \\
18\end{array}$ & $\begin{array}{l}31,0 \\
26,2 \\
42,8\end{array}$ \\
\hline Protein dịch KMNT (g/l) $(n=20)$ & Trung bình \pm SD & & \\
\hline Cấy dịch MNT (n=42) & $\begin{array}{l}\text { Có vi khuẩn } \\
\text { S. aureus } \\
\text { S. pyogenes }\end{array}$ & $\begin{array}{c}15 \\
13 \\
2\end{array}$ & $\begin{array}{c}35,7 \\
30,9 \\
4,8\end{array}$ \\
\hline
\end{tabular}

\section{Nhận xét:}

- 81,0\% bệnh nhân có bạch cầu trong máu ngoại vi $>10 \mathrm{G} / \mathrm{L}$ với số lượng $\mathrm{BC}$ trung bình $18,3 \pm 10.1 \mathrm{G} / \mathrm{L}$; $B C$ cao nhất là $64,1 \mathrm{G} / \mathrm{L}$; thấp nhất là $2,2 \mathrm{G} / \mathrm{L}$ trên $\mathrm{BN}$ có bệnh nền là suy tủy.

-Tất cả các bệnh nhân đều có chỉ số CRP tăng. Có 38 bệnh nhân được xét nghiệm chỉ số procalcitonin, tất cả đều $>0,05 \mathrm{ng} / \mathrm{ml}$.

- Tất cả các trường hợp đều được cấy dịch KMNT tìm vi khuẩn, trong đó có 15 trường hợp (35,7\%) cấy dịch có vi khuẩn, 7 trường hợp $(16,7 \%)$ đồng thời cấy máu và cấy dịch KMNT có cùng một loại vi khuẩn gây bệnh. Vi khuẩn gây bệnh chủ yếu là $S$. aureus chiếm $86,7 \%$ trong các ca cấy dương tính. 


\subsection{Kết quả điều trị viêm mủ màng ngoài tim}

Bảng 4. Phương pháp điều trị VMMNT

\begin{tabular}{|c|c|c|c|c|c|c|c|c|}
\hline \multicolumn{2}{|c|}{ Phương pháp điều trị } & \multicolumn{2}{|c|}{$\begin{array}{l}\text { Chung } \\
n=42\end{array}$} & \multicolumn{2}{|c|}{$\begin{array}{c}\text { Tràn dịch } \\
\text { trung bình } \\
n=16\end{array}$} & \multicolumn{2}{|c|}{$\begin{array}{c}\text { Tràn dịch } \\
\text { nặng } \\
n=26\end{array}$} & \multirow[t]{2}{*}{$\mathbf{p}$} \\
\hline \multirow{4}{*}{ Nội khoa (n=15) } & $\begin{array}{l}\text { Kháng sinh: } \\
\text { Vancomycin } \\
\text { Cefalosporin thế hệ } 3\end{array}$ & $\begin{array}{l}42 \\
35 \\
34\end{array}$ & $\begin{array}{l}100,0 \\
83,3 \\
81,0\end{array}$ & & & & & \\
\hline & Chỉ chọc hút dich MNT & 10 & 23,8 & 6 & 37,5 & 4 & 15,4 & 0,1 \\
\hline & Chọc hút và dẫn lưu dịch MNT & 5 & 11,9 & 2 & 12,5 & 3 & 11,5 & 0,9 \\
\hline & Tai biến chọc vào cơ tim & 4 & 9,5 & 4 & 25,0 & 0 & 0,0 & 0,07 \\
\hline \multirow{4}{*}{ Ngoại khoa (n=27) } & Mổ dẫn lưu MNT & 3 & 7,1 & 2 & 12,5 & 1 & 3,8 & 0,3 \\
\hline & Mở cửa sổ MNT & 2 & 4,8 & 1 & 6,2 & 1 & 3,8 & 0,72 \\
\hline & Cắt MNT & 22 & 52,4 & 5 & 31,2 & 17 & 65,4 & 0,03 \\
\hline & Tai biến phẫu thuật & 0 & 0,0 & & & & & \\
\hline
\end{tabular}

Nhận xét:

- 100\% bệnh nhân sử dụng liệu pháp kháng sinh, kháng sinh được sử dụng nhiều nhất là vancomycin (83,3\%). Có 35,7\% chỉ điều trị nội khoa với chọc hút hoặc dẫn lưu dịch MNT.

- Có 23 trường hợp được thực hiện chọc hút hoặc dẫn lưu MNT trong đó có 8 trường hợp ngoài chọc hút hoặc dẫn lưu còn thực hiện phẫu thuật ngoại khoa sau này. Có 4/23 (17,4\%) gặp tai biến chạm vào cơ tim khi chọc hút xảy ra với số lượng dịch trong khoang MNT ở mức trung bình.

- Chỉ phương pháp ngoại khoa cắt MNT là có sự khác biệt có ý nghĩa thống kê giữa 2 nhóm tràn dịch trung bình và nặng $(p<0,05)$.

Bảng 5. Kết quả điều trị VMMNT

\begin{tabular}{|c|c|c|c|c|c|c|c|c|}
\hline \multirow{2}{*}{\multicolumn{2}{|c|}{ Tình trạng bệnh nhân }} & \multicolumn{2}{|c|}{$\begin{array}{l}\text { Chung } \\
n=42\end{array}$} & \multicolumn{2}{|c|}{$\begin{array}{l}\text { Chỉ điều trị nội khoa } \\
\qquad n=15\end{array}$} & \multicolumn{2}{|c|}{$\begin{array}{c}\text { Có can thiệp } \\
\text { ngoại khoa } \\
n=27\end{array}$} & \multirow{3}{*}{$\begin{array}{c}\mathbf{p} \\
0,14\end{array}$} \\
\hline & & & & & & & & \\
\hline \multirow{5}{*}{$\begin{array}{l}\text { Thời điểm } \\
\text { ra viện }\end{array}$} & & $\mathbf{n}$ & $\%$ & $\mathbf{n}$ & $\%$ & $\mathrm{n}$ & $\%$ & \\
\hline & Ổn định & 24 & 57,1 & 10 & 66,7 & 14 & 51,9 & \multirow{4}{*}{0,37} \\
\hline & Còn ít dịch MNT & 4 & 9,5 & 2 & 13,3 & 2 & 7,4 & \\
\hline & Còn dày màng tim & 14 & 33,3 & 3 & 20,0 & 11 & 40,7 & \\
\hline & Tử vong & 0 & 0,0 & & & & & \\
\hline \multirow{3}{*}{ Khám lại } & Khỏi hoàn toàn & 33 & 78,6 & 13 & 93,3 & 19 & 57,6 & \multirow{3}{*}{0,09} \\
\hline & Còn dày màng tim & 7 & 17,1 & 0 & 13,3 & 7 & 25,9 & \\
\hline & HC Pick & 2 & 4,8 & 1 & 6,7 & 1 & 3,7 & \\
\hline
\end{tabular}

Nhận xét:

- Không có bệnh nhân nào tử vong, 2 trường hợp có biến chứng viêm màng ngoài tim co thắt sau này, 1 bệnh nhân được điều trị nội khoa và 1 bệnh nhân có can thiệp ngoại khoa với mổ dẫn lưu màng ngoài tim. Cả 2 bệnh nhân đều được phát hiện HC Pick sau khoảng 2-3 tháng, sau đó được cắt màng ngoài tim rộng rãi và ổn định.

- Không có sự khác biệt về kết quả điều trị giữa 2 nhóm chỉ điều trị nội khoa và nhóm có can thiệp ngoại khoa $(p>0,05)$. 


\section{BÀN LUÂN}

\section{1. Đặc điểm chung của đối tượng nghiên cứu}

Kết quả nghiên cứu của chúng tôi cho thấy nam chiếm tỷ lệ $61,9 \%$, nữ chiếm tỷ lệ $38,1 \%$. Tỷ lệ nam/nữ là 1,6/1. Kết quả nghiên cứu của chúng tôi phù hợp với kết quả nghiên cứu của một số tác giả trong và ngoài nước về sự phân bố giới tính trong VMMNT. Theo tác giả Lê Hồng Quang (2001) nghiên cứu trên 37 bệnh nhân thì tỷ lệ nam/nữ là 2,36/1 [3]. Nghiên cứu của $O^{\prime}$ Cakir (2002) nghiên cứu trên 18 bệnh nhân tại Thổ Nhĩ Kỳ có tỷ lệ nam/nữ là 1,25/1 [4]. Nguyên nhân của sự khác biệt về giới có thể do trẻ nam hiếu động hơn trẻ nữ nên dễ bị chầy xước da và dễ nhiễm khuẩn hơn. Trong nghiên cứu của chúng tôi độ tuổi trung bình của bệnh nhân là $5,4 \pm 4,3$ tuổi; nhỏ nhất gặp ở trẻ 1 tháng tuổi, cao nhất 15 tuổi.

\section{2. Đặc điểm lâm sàng}

Trong VMMNT sốt là triệu chứng đầu tiên và gặp ở hầu hết các bệnh nhân (97,6\%), chỉ 1 trường hợp bệnh nhân không sốt là bệnh nhân có bệnh nền suy tủy. Triệu chứng cơ năng hay gặp tiếp theo là khó thở $76,2 \%$. Triệu chứng phù chỉ gặp ở 4/42 bệnh nhân chiếm 9,5\%. Các triệu chứng thực thể hay gặp là mạch nhanh $71,4 \%$; gan to $59,5 \%$ trong khi đó tĩnh mạch cổ nổi tự nhiên chỉ được ghi nhận ở 33,3\%, mạch nghịch 19\% các trường hợp. Kết quả này thấp hơn so với nghiên cứu của tác giả Lê Hồng Quang (2001) khi ghi nhận mạch nghịch ở 32,4\% bệnh nhân và tĩnh mạch cổ nổi ở 56,8\% bệnh nhân[3]. Triệu chứng tại tim gồm tiếng tim mờ và tiếng cọ màng ngoài tim, trong khi tiếng tim mờ được ghi nhận ở $66,7 \%$ các trường hợp thì tiếng cọ MNT chỉ được ghi nhận ở 9,5\% các trường hợp do tiếng cọ MNT thường xuất hiện trong giai đoạn rất sớm hoặc muộn khi dịch rút lui, nó xuất hiện và mất đi nhanh đồng thời còn phụ thuộc vào khả năng người phát hiện nên dễ bị bỏ qua. Kết quả này thấp hơn kết quả của tác giả Abdel Haq khi ghi nhận tiếng cọ MNT ở 19\% các trường hợp[5].

Có 64,3\% số bệnh nhân phát hiện triệu chứng tại cơ quan khác với $52,4 \%$ bệnh nhân có tràn dịch màng phổi; $45,2 \%$ có viêm phế quản phổi; $16,7 \%$ có nhiễm trùng da và mô mềm; $2,4 \%$ có viêm cơ và không có trường hợp nào có cốt tủy viêm hay viêm màng não mủ, phần lớn trong số này có tràn dịch màng phổi và viêm phế quản phổi đồng thời. Điều này phù hợp với nhận định VMMNT đa số là nhiễm trùng thứ phát.

\section{3. Đặc điểm cận lâm sàng}

Trên Xquang ngực thẳng có 41/42 (97,6\%) bệnh nhân có tỷ lệ tim ngực tăng, chỉ số tim ngực trung bình là $62,2 \pm 6,2 \%$. Có $38 / 42$ bệnh nhân được chụp lại, chỉ số tim ngực có xu hướng giảm sau khi điều trị, sự khác biệt có ý nghĩa thống kê với $p<0,01$. Trên điện tâm đồ chúng tôi thu được 40,5\% bệnh nhân có điện thế ngoại biên $\leq 5 \mathrm{~mm}$; $11,9 \%$ bệnh nhân có điện thế chuyển đạo trước tim <10mm; 19\% bệnh nhân có đoạn ST chênh lên và sóng $T$ dương; $26,2 \%$ bệnh nhân có đoạn ST chênh xuống hoặc đẳng điện và $T$ âm trên các chuyển đạo ngoại vi và trước tim. Nghiên cứu của HE Tutar (2002) trên 62 bệnh nhân cũng cho kết quả tương tự với $55 \%$ bệnh nhân có giảm điện thế ngoại biên; $29 \%$ bệnh nhân có đoạn ST chênh lên và sóng $\mathrm{T}$ dương; $10 \%$ bệnh nhân có sóng $\mathrm{T}$ chênh xuống và sóng $T$ âm [6]. Siêu âm tim cho kết quả $100 \%$ bệnh nhân có tràn dịch màng ngoài tim (TDMNT) mức độ trung bình hoặc nặng, trong đó TDMNT mức độ nặng chiếm 61,9\%. Có $61,9 \%$ bệnh nhân có xẹp nhĩ phải, $23,8 \%$ bệnh nhân có xẹp thất phải, dịch có sợi fibrin gặp trong $81 \%$ các trường hợp và $35,7 \%$ có dày màng tim trên siêu âm. Khi so sánh giữa 2 nhóm tràn dịch mức độ trung bình và mức độ nặng, chỉ có triệu chứng mạch nhanh, mạch nghịch và huyết áp hạ có sự khác biệt giữa 2 nhóm $(p<0,05)$.

Xét nghiệm máu cho kết quả hầu hết các bệnh nhân có tăng bạch cầu trong máu ngoại vi với số lượng $\mathrm{BC}$ trung bình $18,3 \pm 10.1 \mathrm{G} / \mathrm{L}$; tỷ lệ $\mathrm{BC}$ trung tính trung bình $79,6 \pm 8,3 \%$. Tất cả các bệnh nhân đều có chỉ số CRP tăng với giá trị CRP trung bình

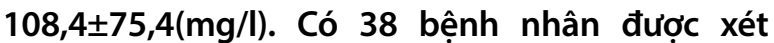
nghiệm chỉ số procalcitonin, tất cả đều $>0,05 \mathrm{ng} / \mathrm{ml}$ trong đó 25 bệnh nhân $(64,3 \%)$ có procalcitonin $>0,5 \mathrm{ng} / \mathrm{ml}$ có ý nghĩa đáp ứng viêm hệ thống từ tương đối tới nghiêm trọng [7]. Có 8 trường hợp cấy máu có vi khuẩn, trong đó 7 trường hợp là tụ cầu vàng, 1 trường hợp là $S$. pyogenes (liên cầu sinh mủ). Có 15 trường hợp $(35,7 \%)$ cấy dịch có vi 
khuẩn trong đó 13 trường hợp là S. aureus 2 trường hợp là S. pyogenes. Như vậy có 35,7\% bệnh nhân có bệnh cảnh nhiễm khuẩn huyết với biểu hiện đáp ứng viêm toàn thân và nhiễm trùng đã được chứng minh khi tìm thấy vi khuẩn trong dịch màng tim hoặc trong máu; $7 / 42$ bệnh nhân (16,7\%) cấy dịch và cấy máu xác định cùng tác nhân vi khuẩn và tụ cầu vàng vẫn là nguyên nhân gây bệnh chủ yếu tương tự như nghiên cứu của tác giả Lê Hồng Quang có $11 / 37$ bệnh nhân $(29,7 \%)$ cấy dịch có vi khuẩn, trong đó $100 \%$ tụ cầu vàng và chỉ có 3 bệnh nhân $(8,1 \%)$ cấy dịch và cấy máu có vi khuẩn.

\subsection{Phương pháp và kết quả điều trị}

Trong nghiên cứu của chúng tôi 42 bệnh nhân đều được điều trị kháng sinh phổ rộng hoặc kháng sinh diệt tụ cầu khi có kết quả cấy máu, cấy dịch hoặc có bệnh cảnh nghi ngờ do tụ cầu (mụn nhọt da, áp xe cơ...). Tất cả 13 trường hợp cấy dịch dương tính với $S$. aureus đều được làm kháng sinh đồ, tất cả đều thuộc nhóm tụ cầu vàng kháng methicillin (MRSA).

Có $27 / 42$ các trường hợp (63,3\%) được điều trị ngoại khoa, tỷ lệ này tương đương so với các nghiên cứu khác với tỷ lệ điều trị ngoại khoa từ 60-80\% [3], [4]. Không có bệnh nhân nào tử vong trong nghiên cứu của chúng tôi, tất cả các bệnh nhân đều đã hết các triệu chứng lâm sàng (hết sốt, khó thở, tiếng tim rõ, mất tiếng cọ MNT). Tất cả 42 trường hợp đều được tái khám và theo dõi sau khi ra viện, không phát hiện trường hợp nào tái phát, chỉ còn 7 trường hợp $(17,1 \%)$ còn dày màng tim trên siêu âm và có 2 trường hợp có viêm màng ngoài tim co thắt đã được phẫu thuật cắt MNT rộng rãi và cho kết quả tốt. Trong phạm vi nghiên cứu này, không có sự khác biệt về kết quả điều trị có ý nghĩa thống kê giữa 2 nhóm chỉ điều trị nội khoa và nhóm có can thiệp ngoại khoa.

\section{KẾT LUẬN}

Bệnh nhân mắc bệnh viêm mủ màng ngoài tim có các đặc điểm: tuổi trung bình 5,4 tuổi; gặp nhiều hơn ở trẻ nam; biểu hiện nhiễm trùng toàn thân, các triệu chứng định hướng chẩn đoán gồm khó thở $76,2 \%$, mạch nhanh $71,4 \%$, gan to $59,5 \%$, đau ngực $52,4 \%$, tiếng tim mờ $66,7 \%$, tiếng cọ MNT ít gặp; Trên siêu âm tim $100 \%$ bệnh nhân có tràn dịch MNT vừa đến nặng. Tỷ lệ cấy máu và cấy dịch màng ngoài tim dương tính không cao, nguyên nhân chủ yếu là tụ cầu vàng. Điều trị phối hợp nội ngoại khoa, đặc biệt cắt màng ngoài tim rộng rãi cho kết quả tốt.

\section{TÀI LIỆU THAM KHẢO}

1. Adler Y., Charron P., Imazio M., et al. (2015). 2015 ESC Guidelines for the diagnosis and management of pericardial diseases: The Task Force for the Diagnosis and Management of Pericardial Diseases of the European Society of Cardiology (ESC)Endorsed by: The European Association for Cardio-Thoracic Surgery (EACTS). Eur Heart J, 36(42), 2921-2964.

2. Võ Thị Phương Liên (2010). Nghiên cứu đặc điểm viêm màng ngoài tim tại Bệnh viện Nhi Đồng 1, Luận văn Thạc sĩ y học, Trường Đại học $Y$ Dược TP Hồ Chí Minh.

3. Lê Hồng Quang (2001). Nghiên cứu đặc điểm lâm sàng và siêu âm trong chẩn đoán viêm mủ màng ngoài tim ở trẻ em, Luận văn Thạc sĩ $Y$ học, Trường Đại học $Y$ Hà Nội.

4. Çakir Ö., Gurkan F., Balci A.E., et al. (2002). Purulent pericarditis in childhood: Ten years of experience. Journal of Pediatric Surgery, 37(10), 1404-1408.

5. Abdel-Haq N., Moussa Z., Farhat M., et al. (2018). Infectious and Noninfectious Acute Pericarditis in Children: An 11-Year Experience. International journal of pediatrics.

6. Tutar H.E., Yilmaz E., Atalay S., et al. (2002). The changing aetiological spectrum of pericarditis in children. Annals of Tropical Paediatrics, 22(3), 251-256.

7. Reinhart K., Brunkhorst F., Bone $H_{\text {., }}$ et al. (2006). [Diagnosis and therapy of sepsis. Guidelines of the German Sepsis Society Inc. and the German Interdisciplinary Society for Intensive and Emergency Medicine]. Internist (Berl), 47(4), 356, 358-360, 362-368. 